\title{
Managing Salinity in Citrus
}

\author{
Brian J. Boman ${ }^{1}$, \\ Mongi Zekri ${ }^{2}$, and Ed Stover ${ }^{3}$
}

ADDITIONAL INDEX wORDs. irrigation, management, fertilization

Summary. Although citrus (Citrus spp.) is sensitive to salinity, acceptable production can be achieved with moderate salinity levels, depending on the climate, scion cultivar, rootstock, and irrigation-fertilizer management. Irrigation scheduling is a key factor in managing salinity in areas with salinity problems. Increasing irrigation frequency and applying water in excess of the crop water requirement are recommended to leach the salts and minimize the salt concentration in the root zone. Overhead sprinkler irrigation should be avoided when using water containing high levels of salts because salt residues can accumulate on the foliage and cause serious injury. Much of the leaf and trunk damage associated with direct foliar uptake of salts can be reduced by using microirrigation systems. Frequent fertilization using low rates is recommended through fertigation or broadcast application of dry fertilizers. Nutrient sources should have a relatively low salt index and not contain chloride $(\mathrm{Cl})$ or sodium $(\mathrm{Na})$. In areas where $\mathrm{Na}$ accumulates in soils, application of calcium $(\mathrm{Ca})$ sources (e.g., gypsum) has been found to reduce the deleterious effect of $\mathrm{Na}$ and improve plant growth under saline conditions. Adapting plants to saline environments and increasing salt tolerance through breeding and genetic manipulation is another important method for managing salinity.

\section{Salinity measurement}

The objective of this article is to review practical methods

( for managing salinity in citrus

Florida Agricultural Experiment Station Journal Series No. R-10230.

${ }^{1}$ University of Florida, IFAS, Indian River Research and Education Center, 2199 S. Rock Rd., Ft. Pierce, FL 34945 . To whom reprint requests should be addressed. E-mail address: bjboman@ifas.ufl.edu

${ }^{2}$ University of Florida, IFAS, Hendry County Extension Office, P.O. Box 68, LaBelle, FL 33975.

${ }^{3}$ USDA/ARS National Clonal Germplasm Repository, One Shields Ave., Davis, CA 95616-8607. 
production. Saline irrigation water and fertilizer application are the factors most responsible for increasing soil salinity (Jones et al., 1952). All natural waters and soil solutions contain soluble salts. The salinity of irrigation water is defined as the concentration of dissolved mineral salts present in the water on a unit volume or weight basis. The major components of salinity are the cations $\mathrm{Ca}$, magnesium $(\mathrm{Mg})$, and $\mathrm{Na}$, and the anions $\mathrm{Cl}$, sulfate $\left(\mathrm{SO}_{4}\right)$, and bicarbonate $\left(\mathrm{HCO}_{3}\right)$ (Pratt and Suarez, 1990). With the exception of boron (B), the effects of other minor dissolved constituents [e.g., nitrate $\left(\mathrm{NO}_{3}\right)$ and potassium $\left.(\mathrm{K})\right]$ are generally excluded in assessing salinity of irrigation water supplies.

Salt concentration in water is commonly reported in units of total dissolved solids (TDS) or electrical conductivity (EC). TDS are measured by evaporating a sample of water and weighing the residue. The results are reported in parts per million (ppm) or milligrams per liter $\left(\mathrm{mg} \cdot \mathrm{L}^{-1}\right)$, depending on whether the calculation is on a weight or volume basis. For most practical purposes, ppm are equal to $\mathrm{mg} \cdot \mathrm{L}^{-1}$. Salts in solution exist as ions that conduct electrical current, and the EC increases with higher concentrations of dissolved salts. EC measurements are taken with platinum electrodes and presented in units of conductance such as decisiemens per meter $\left(\mathrm{dS} \cdot \mathrm{m}^{-1}\right)$, generally resulting in a value from 0 to 5 for most irrigation waters. The conversion from electrical conductance to TDS depends on the particular salts present in the solution. For most conditions, the TDS (expressed as $\mathrm{mg} \cdot \mathrm{L}^{-1}$ ) can be estimated by multiplying the EC (in $\mathrm{dS} \cdot \mathrm{m}^{-1}$ ) by a factor ranging from 500 to 750 , with the higher values generally associated with waters high in sulfate concentration (Hem, 1970). A typical conversion factor used for many areas of the world is: $\mathrm{dS} \cdot \mathrm{m}^{-1} \times 640=\mathrm{mg} \cdot \mathrm{L}^{-1}$ (Tanji, 1990).

Since the concentration of salts in soil depends on soil water content, soil salinity is often related to the electrical conductivity of standard saturated extract $\left(\mathrm{EC}_{\mathrm{e}}\right) . \mathrm{EC}_{\mathrm{e}}$ standardizes the amount of salts in the soil to conditions when the soil is saturated. Depending on soil moisture content, the actual salinity level in the vicinity of the tree roots may be several times greater than the $\mathrm{EC}_{\mathrm{e}}$. In sandy soils, where salts are easily leached, management decisions based solely on $\mathrm{EC}_{\mathrm{e}}$ measurements are not advised. The $\mathrm{EC}_{\mathrm{e}}$ of these soils is only an indication of soil salinity at the time of measurement and can change rapidly following drought, fertilization, irrigation, or rainfall.

\section{Salt injury}

The primary citrus tree response to excess salts in irrigation water and soil solutions is a reduction of growth. Salts in solution exert an osmotic effect, measured by osmotic potential, that reduces the availability of free (unbound) water through both chemical and physical processes. Therefore, roots are not able to extract as much water from a solution that is high in salts as from one low in salts. This can result in reductions in root growth, shoot growth, and yield. The critical salinity level will vary with the buffering capacity of the soil (soil type, organic matter) and climatic conditions (which affect daily water requirements) and the soil moisture status (Shalhevet et al., 1974). In humid areas, the injury symptoms on citrus trees caused by saline irrigation water are not usually permanent. However, affected trees may remain stunted compared to trees not receiving salinized water, especially if the trees are young when they are salt stressed.

Citrus is also sensitive to the toxic effect of accumulated $\mathrm{Cl}$ and $\mathrm{Na}$ in the leaves (Cooper, 1961; Cooper et al., 1952; Furr and Ream, 1968; Grieve and Walker, 1983). Goell (1969) suggested that salt ions such as $\mathrm{Cl}$ in citrus leaves might shorten the life span of leaves by increasing chlorosis and by promoting senescence and abscission. The accumulation of ions in large amounts in the leaves may be the main factor causing leaf burn and inhibition of certain metabolic processes. Salt can also damage plants by causing nutritional imbalances. In citrus, nutritional imbalance has been also attributed to depressed absorption of some nutrients. A decrease in the concentration of calcium, magnesium, and sometimes potassium was found when salt concentration in the irrigation water was increased (Pearson et al., 1957; Zekri and Parsons, 1992).

Sodium can also cause injury to plants through its deleterious effect on the soil by dispersing clay particles, blocking soil pores, decreasing water infiltration, and causing poor aeration.
Studies by Aldrich et al. (1945) demonstrated that inferior performance of sweet orange (C. sinensis) trees was caused primarily by poor water penetration into soil resulting from $\mathrm{Na}$ accumulation on the exchange complex. Plant extraction of water from soil is osmotically more difficult under saline solutions. Therefore, increasing salt in soil water is analogous to soil drying since both reduce water potential and result in decreased water uptake.

Salinity can cause canopy thinning, severe leaf drop, and twig dieback. Salt stress can also delay fruit maturation and reduce fruit yield by decreasing the number of fruit per tree and the size of fruit produced. The critical salinity level will vary with the buffering capacity of the soil (soil type, organic matter), climatic conditions, and the soil moisture status (Levy and Boman, 2004). Many salinity-induced symptoms, such as decreased flowering, smaller leaf size, impaired shoot growth, and reduced root growth, are often difficult to assess but occur prior to ion toxicity symptoms in leaves. Chloride toxicity, consisting of burned, necrotic, or dry-appearing edges or tips of leaves, is one of the most common visible salt injury symptoms. Toxicity symptoms usually appear when leaf $\mathrm{Cl}$ levels reach about $1 \%$ of leafdry weight (Chapman, 1968) but, based on reductions in yield, a leaf $\mathrm{Cl}$ concentration of as little as $0.2 \%$ should be considered excessive (Koo et al., 1984). The critical $\mathrm{Cl}$ concentration varies with climate, humidity, and tree water use.

Visible Na toxicity symptoms appear when leaf $\mathrm{Na}$ levels reach $0.10 \%$ to $0.25 \%$ of leaf dry weight (Chapman, 1968). Again, such symptoms vary with climatic conditions. In humid climates, Na toxicity symptoms seldom distinctly appear. Sometimes an overall leaf "bronzing" appears along with reductions in growth. As with $\mathrm{Cl}$, high leaf $\mathrm{Na}$ can cause nutrient imbalances at much lower concentrations than those required for visible symptoms, and high $\mathrm{Na}$ in leaves can be physiologically even more detrimental than excess $\mathrm{Cl}$ (Syvertsen et al., 1988).

The sensitivity of citrus scion/ rootstock combination to injury through direct foliar contact bears no relationship to its general tolerance to soil salinity. LeafCl and $\mathrm{Na}$ toxicity due to direct contact with saline water has different symptoms than toxicity of $\mathrm{Cl}$ 
that was absorbed by roots. Contact damage, consisting of burned, necrotic, or dry-appearing tips on leaves, is one of the most common visible salt injury symptoms. Controlled experiments showed that citrus leaves easily accumulate $\mathrm{Cl}$ and $\mathrm{Na}$ from direct contact with water drops (Eaton and Harding, 1959, and Ehlig and Bernstein, 1959). Harding et al. (1958a) reported that wetting of lower leaves of citrus trees with saline irrigation water resulted in 3 to 4 times as much $\mathrm{Na}$ and $\mathrm{Cl}$ as in the upper leaves, which were not wetted. Accumulation depends on the rate of evaporation, which results in increased salt concentration of the water film on the leaves. Similar damage can also develop from wind-blown salt near the sea.

It is important to remember that growth and yield of trees on all rootstocks can be reduced by excessive salts. Salt- $(\mathrm{Cl})$ tolerant rootstocks tend to produce trees that grow more slowly or that use less water than trees on many salt-sensitive rootstocks. The comparatively high tolerance to salinity of sour orange (C. aurantium) rootstock creates a dilemma since growers must balance the risk of sour orange's high sensitivity to citrus tristeza virus (CTV) with its favorable responses to salinity, and many tristeza-tolerant rootstocks are sensitive to salinity. Younger dripirrigated trees on sour orange rootstock may be more susceptible to salinity than mature trees (Levy et al., 1999a). The salinity tolerance of scions also may be related to water usage. Grapefruit (C. paradisi) and lemon (C. limon) trees tend to use more water and are less salt tolerant than sweet orange cultivars (Cooper et al., 1952; Levy and Shalhevet, 1985).

\section{Salt tolerance}

Citrus is classified as a salt-sensitive crop because physiological disturbances and reductions in growth and fruit yield can occur at relatively low salinity levels (Bernstein, 1969; Bielorai et al., 1978; Boaz, 1978; Kirkpatrick and Bitters, 1969; Maas, 1993; Walker et al., 1983; Zekri and Parsons, 1989). However, citrus trees can withstand moderate salinity levels without great disruption, depending on the climate, scion cultivar, rootstock, and irrigationfertilizer management. Salt tolerance in citrus has been related to ion exclusion because of the plant's inability to compartmentalize toxic ions in a useful way and to adjust osmotically (Greenway and Munns, 1980).

Citrus tolerance to salinity can be correlated with its ability to restrict the entry of ions into the shoots (Greenway and Munns, 1980). Exclusion of certain ions has been demonstrated in some citrus rootstocks. 'Rangpur' lime (C. limonia) and 'Cleopatra' mandarin (C. reshnii) appear to be $\mathrm{Cl}$ excluders (Cooper, 1961; Cooper and Gorton, 1952; Cooper and Peynado, 1959; Grieve and Walker, 1983; Hewitt and Furr, 1965; Walker et al., 1983; Wutscher et al., 1973; Zekri and Parsons, 1992). Trifoliate orange (Poncirus trifoliata) and its hybrids appear to be $\mathrm{Na}$ excluders (Grieve and Walker, 1983; El Gazzar et al., 1965; Zekri and Parsons, 1992), and C. macrophylla a B excluder (Cooper and Peynado, 1959; Embleton et al., 1962). This suggests the existence of a blocking mechanism in the transport of these ions. It also indicates the existence of apparently separate mechanisms that regulate the uptake and transport of ions $(\mathrm{Cl}$ and $\mathrm{Na}$ ) in salt-stressed citrus (Grieve and Walker, 1983; Walker et al., 1983).

Several studies have shown that citrus rootstocks differ in their salinity tolerance (Cooper and Gorton, 1952; Wutscher, 1979). Field studies in Texas (Chapman, 1968; Cooper, 1961) and California (Newcomb, 1978) tested salinity tolerance of rootstocks according to their ability to exclude $\mathrm{Cl}$ from leaves. These results have been corroborated more recently for many rootstocks under field conditions (Levy and Shalhevet, 1990; Levy et al., 1999a, 1999b). In general, the decreasing order of salinity tolerance (most tolerant to most sensitive) is: 'Cleopatra' mandarin, 'Rangpur' lime, 'SB812' (C. sunki $\times$ P. trifoliata), 'x639' (C. reshnix P. trifoliata), 'Gau Tou' (Citrus hybrid), 'Volkameriana' (C. volkameriana), sour orange, 'Swingle' citrumelo, rough lemon (C. jambhiri), 'Carrizo' and 'Troyer' citranges (C. sinensis $\mathrm{X}$ P. trifoliata), ' $\mathrm{C} 35$ ' citrange, citron (C. medica). The above ranking may be changed somewhat by the effect of scion, and conditions of incompatibility, which can be physiological or pathological (viruses, viroids, root infections).

\section{Irrigation management}

When the irrigation water is saline, the irrigation method greatly influences tree performance. Shalhevet (1984) described three factors that should be considered before selecting an irrigation method: 1) the salt distribution in the soil; 2) the sensitivity of the crop to foliar wetting; and 3 ) the ease with which high osmotic and matric potentials can be achieved.

Good irrigation management should consider the salinity factor in the irrigation water, in the soil, and in the root zone (Boaz, 1978). Methods of irrigation scheduling that do not account for salinity are not suitable for scheduling irrigation in areas with a salinity problem. Irrigation water containing about $250 \mathrm{mg} \cdot \mathrm{L}^{-1}$ of $\mathrm{Cl}$ reduced grapefruit yield by $28 \%$ to $32 \%$ when trees were irrigated at intervals of $40 \mathrm{~d}$ compared to intervals of $18 \mathrm{~d}$ (Bielorai et al., 1973). These studies demonstrated that the effect of salinity is more severe at lower soil water content.

Trees irrigated with sprinkler irrigation systems are subject to injury not only from salts in the soil but also from salts absorbed directly through wetted leaf surfaces (Maas, 1985). Overhead sprinkler irrigation should be avoided when using water containing high levels of salts because salt residues can accumulate on the foliage and seriously injure plants. Navel orange accumulated injurious amounts of $\mathrm{Cl}$ and $\mathrm{Na}$ from sprinkler-applied water having 500 to $900 \mathrm{mg} \cdot \mathrm{L}^{-1}$ TDS (Harding et al., 1958a). Considerable leaf burn and defoliation of these trees were found to be correlated with excessive amounts of $\mathrm{Na}$ and $\mathrm{Cl}$ and lower amounts of $\mathrm{K}$ in the leaves. Leaf injury of navel orange trees developed at concentrations of 5 tol $0 \mathrm{mmol} \cdot \mathrm{L}^{-1}$ of sodium chloride $(\mathrm{NaCl})$, calcium chloride $\left(\mathrm{CaCl}_{2}\right)$, or sodium sulfate $\left(\mathrm{Na}_{2} \mathrm{SO}_{4}\right)$ in the sprinkler-applied waters (Ehlig and Bernstein, 1959). Salt content of up to $1300 \mathrm{mg} \cdot \mathrm{L}^{-1}$ caused defoliation of sprinkler-irrigated citrus trees (Lyons, 1977). During periods of high salinity in the irrigation water, foliar absorption of $\mathrm{Na}$ and $\mathrm{Cl}$ occurred when using overhead sprinklers on citrus. It was believed that this problem caused poor tree health, low yield, and possibly poor fruit quality in citrus (Cole and Till, 1977). Comparative studies between overhead sprinklers and drip systems using saline water showed that vegetative growth, root development, and yield were greater with drip than with sprinkler irrigation (Goldberg and Shmueli, 1971; Shmueli and Goldberg, 
1971). In a comparison of flood and drip systems, water high in $\mathrm{Cl}$ and $\mathrm{B}$ was applied to young grapefruit trees on many rootstocks (Wutscher et al., 1973). More $\mathrm{Cl}$ and $\mathrm{B}$ accumulation was found in flood-irrigated trees than in microirrigated trees.

Frequency rather than duration of sprinkler irrigation is perhaps more important in foliar absorption of salts. Salt injury was greater under higher evaporation conditions and with short and frequent periods of overhead sprinkling (Eaton and Harding, 1959; Ehlig and Bernstein, 1959; Harding et al., 1958a). It is important to keep poor quality water offleaves, especially under conditions of high evaporative demand, and to irrigate at night whenever possible to minimize evaporative concentration of salts (Boman and Stover, 2002). Other strategies to minimize foliar injury from sprinkling include irrigating below the canopy to eliminate or reduce wetting of the foliage and avoiding intermittent wetting that results in repeated wetting and drying cycles (Maas, 1985, Syvertsen et al., 1989)

Successful irrigation management to control soil salinity requires adequate leaching. Irrigation rates should be monitored to make sure that excess salts are leached below the root zone. Leaching should remove enough salts and prevent their build-up to damaging levels (Maas, 1993). However, excessive leaching can lead to loss of some essential nutrients. Poorly drained, heavy soils or soils with perched water tables may be difficult to leach properly because of inadequate permeability or drainage.

Drip irrigation at frequent intervals maintains a low soil water tension and prevents salt accumulation within the wetted zone. More frequent irrigations resulted in less depletion of soil water by the trees between irrigations, thus reducing average soil salt concentration and salt uptake by the trees (Grieve, 1983). Consequently, water with higher salinity levels may be used without significantly affecting the yield. Nevertheless, salt accumulation under drip irrigation must be considered because salts may accumulate both at the periphery of the wetted zone and on the soil surface (Bielorai, 1977, 1985).

In arid climates, especially under drip irrigation, special care should be taken to prevent salt damage caused by the first rains after a long drought period. Rain may leach the salts into the root zone that had accumulated on the soil surface or the periphery of the wetted zone. Irrigation should thus be started immediately when the rain begins; postponing irrigation for even a short period may result in severe damage, typically defoliation.

\section{Fertilizer management}

Since salinity can cause nutritional imbalances by displacing certain nutrients, salinity damage can be reduced if adequate nutritional levels are maintained (Boman and Stover, 2002). Adopting a fertilizer program that uses frequent applications with relatively low concentrations of salts is recommended. Controlled-release fertilizers and frequent fertigations are ways to minimize salt stress when using high salinity water. Selecting nutrient sources that have a relatively low salt index in the soil solution can help reduce salt stress. Fertilizer sources containing high amounts of $\mathrm{Cl}$ or $\mathrm{Na}$ [such as potassium chloride $(\mathrm{KCl})$ and sodium nitrate $\left(\mathrm{NaNO}_{3}\right)$ ] should be avoided to minimize compounding of salinity problems (Boman and Stover, 2002).

High rates of salt application can alter soil $\mathrm{pH}$ and thus cause soil nutrient imbalances. Specific ions can also add to potential nutrient imbalances in soil and trees. For example, $\mathrm{Na}^{+}$displaces $\mathrm{K}^{+}$, and to a lesser extent $\mathrm{Ca}^{++}$, in soil. This can lead to $\mathrm{K}$ deficiencies and, in some cases, even to $\mathrm{Ca}$ deficiencies in leaves when irrigating repeatedly with water high in Na. Such nutrient imbalances can compound the effects of salinity stress. Problems can be minimized if adequate nutritional levels are maintained, especially those of $\mathrm{K}$ and $\mathrm{Ca}$.

Calcium has been known to have an ameliorating effect on the growth of plants under saline conditions. Calcium can flocculate soil in which clay particles and aggregates have been dispersed by Na. Salt-affected soils can therefore be made productive by chemical amendment, drainage, and irrigation with high quality water, but sometimes the cost of these operations exceeds the expected returns from the land. Application of gypsum to the soil or in the irrigation water markedly reduced the percentage of soluble $\mathrm{Na}$ in the soil (Harding et at., 1958b) and reduced the percentage of $\mathrm{Na}$ in citrus leaves and roots (Jones et al., 1952; Pearson and Huberty, 1959). The addition of calcium sulfate $\left(\mathrm{CaSO}_{4}\right)$ to saline solutions was found to be slightly beneficial to some citrus rootstocks by reducing $\mathrm{Na}$ and/or $\mathrm{Cl}$ concentrations in the shoots, increasing $\mathrm{Ca}$ content, and improving final emergence and seedling growth (Zekri, 1993). Zekri and Parsons (1990) demonstrated that the ability of sour orange seedlings to withstand saline irrigation water was improved by the addition of $\mathrm{Ca}$ to the water. The beneficial effect of $\mathrm{CaSO}_{4}$ addition to the saline irrigation water was mainly attributed to a reduction in the accumulation of $\mathrm{Na}$ and $\mathrm{Cl}$ below the toxicity level in the leaves without a major increase in total dissolved salts. Zekri and Parsons (1990) also showed that the beneficial effect of adding $\mathrm{Ca}$ depended on the anion associated with the $\mathrm{Ca}$ salt, with a higher growth rate for $\mathrm{NaCl}$-stressed sour orange seedings receiving $\mathrm{CaSO}_{4}$ compared to $\mathrm{CaCl}_{2}$.

The use of enhanced $\mathrm{K}$ plant nutrition is an efficient method of preventing $\mathrm{Na}$-induced stress in many crops. In addition, the use of enhanced $\mathrm{NO}_{3}$ fertilization is a potent tool in precluding chloride-induced stress in many crops (Achilea, 2002). Salinity treatments $(6.6-18 \mathrm{~mm}$ of $\mathrm{Cl})$ markedly increased $\mathrm{Cl}$ and $\mathrm{Na}$ contents of grapefruit leaves, thereby reducing the total yield of the trees and their canopy volumes. However, by maintaining a constant concentration of 2 mu potassium nitrate $\left(\mathrm{KNO}_{3}\right)$ in the irrigation water, the adverse effects of salinity treatments on the trees were avoided and yields increased up to $38 \%$. Addition of $\mathrm{NO}_{3}$ to the irrigation water reduced $\mathrm{Cl}$ accumulation in the plant and alleviated its adverse effects. High $\mathrm{NO}_{3}$ fertilization was also found to reduce $\mathrm{Cl}$ accumulation and toxic symptoms as well as B concentrations in the leaves (Bar et al., 1997). The results of this study suggested that water containing high $\mathrm{Cl}$ levels may be used to irrigate citrus orchards, provided that $\mathrm{NO}_{3}$ is supplied continuously at a molar concentration equivalent to half that of $\mathrm{Cl}$. It is also suggested that a $\mathrm{NO}_{3}$ supplement be applied to citrus to reduce the undesirable uptake of $\mathrm{B}$.

\section{Genetic improvement}

Cultivars, rootstocks, irrigation, and fertilization management all are important factors to consider concerning salinity management in citrus 
(Levy and Syvertsen, 2004). However, adapting plants to saline environments through breeding and genetic manipulation may be a long-term solution to salinity problems. Results from screening hybrids indicate that $\mathrm{Cl}$ exclusion of rootstock is heritable. Ream and Furr (1976) found that Cleopatra mandarin and Rangpur hybrids were as effective as their parents in restricting $\mathrm{Cl}$ transport.

In some species, the variability in salt tolerance may not be adequate for a successful breeding program because it may not be possible to find salttolerant wild relatives and use them as sources of germplasm. Selection of cell lines for high salt tolerance in vitro has been pursued with the aim of developing more salt-tolerant citrus types (Ben-Hayyim and Kochba, 1983; Garcia-Agustin and Primo-Miloo, 1995; Kochba et al., 1982; Libal-Weksler et al., 1994; Piqueras et al., 1996). Selection in solutions having various degrees of osmotic stress was found to be a promising technique to identify salt-tolerant cells among salt-sensitive cells (Croughan et al., 1981), which implies that the genetic information for growth in a saline environment may be present in salt-sensitive cells but is not expressed. Such salt-tolerant cells may improve our understanding of salinity resistance at the cellular level. However, attempts to develop more salt-tolerant plants from salt-tolerant cells or tissue cultures have had little success (BenHayyim and Goffer, 1989; Spiegel-Roy and Ben-Hayyim, 1985). NaCl-selected salt resistance of somatic cells has not been translated into increased resistance of whole plants in the field, largely because salt resistance in citrus, like most plants (Dracup, 1993), appears to be a multigenic trait (Storey and Walker, 1999).

Like most glycophytes, salt tolerance in citrus is associated with the restriction of $\mathrm{Na}$ and $\mathrm{Cl}$ transport from the root to the shoot. This suggests that breeding and selection for $\mathrm{Cl}$ - and $\mathrm{Na}$ excluding genotypes will continue to be a potential area of research (Storey and Walker, 1999). However, breeding alone will probably not solve the problems of salinity. Breeding should be viewed as part of a total package including the management of irrigation and drainage (Flowers and Yeo, 1995 ).

In spite of a significant amount of research on the effects of salinity on plants, there has been little success in getting salt-tolerant plants into commercial production, probably because salinity has not been a problem of sufficient priority (Flowers and Yeo, 1995). Progress in genetic engineering may open ways to manipulate citrus salt resistance by insertion of specific resistance genes. However, physiological processes involved in $\mathrm{Na}$ and $\mathrm{Cl}$ restriction, uptake, transport, and accumulation must be well understood (Storey and Walker, 1999).

\section{Literature cited}

Achilea, O. 2002. Alleviation of salinity-induced stress in cash crops by multi-K (potassium nitrate), five cases typifying the underlying pattern. Acta Hort. 573:43-48.

Aldrich, D.G., E.R. Parker, and H.D. Chapman. 1945. Effects of several nitrogenous fertilizers and soil amendments on the physical and chemical properties of an irrigated soil. Soil Sci. 59:299-312.

Bar, Y., A. Apelbaum, U. Kafkafi, and R. Goren. 1997. Relationship between chloride and nitrate and its effect on growth and mineral composition of avocado and citrus plants. J. Plant Nutr. 20(6):715-731.

Ben-Hayyim, G. and J. Kochba. 1983. Aspects of salt tolerance in a $\mathrm{NaCl}$-selected stable cell line of Citrus sinensis. Plant Physiol. 72:685-690.

Ben-Hayyim, G. and Y. Goffer. 1989. Plantlet regeneration from a $\mathrm{NaCl}$-selected callus culture of Shamouti orange (Citrus sinensis L. Osbeck). Plant Cell Rpt. 7:680-683.

Bernstein, L. 1969. Salinity factors and their limits for citrus culture. Proc. First Intl. Citrus Symp. 3:1779-1782.

Bielorai, H. 1977. The effect of drip and sprinkler irrigation on grapefruit yield, water use and soil salinity. Proc. Intl. Soc. Citricult. 1:99-103.

Bielorai, H. 1985. Moisture, salinity and root distribution of drip irrigated grapefruit. Proc. Third Intl. Drip/Trickle Irr. Congr. 2:562-567.

Bielorai, H., Y. Levy, and J. Shalhevet. 1973. The effect of irrigation frequency and water quality on grapefruit yield, water use and soil salinity. Proc. Intl. Soc. Citricult. $1: 257-263$

Bielorai, H., J. Shalhevet, and Y. Levy. 1978. Grapefruit response to variable salinity in irrigation water and soil. Irr. Sci. 1:61-70.

Boaz, M. 1978. Salinity management in citrus. Proc. Intl. Soc. Citricult. 1:233-234.

Boman, B.J. and E.W. Stover. 2002. Managing salinity in Florida citrus. Univ. of Florida, IFAS, Coop. Ext. Circ. 1411. Gainesville.
Chapman, H.D. 1968. Salinity and alkali, p. 243-266. In: W. Reuther, L.D. Batchelor, and H.J. Weber (eds.). The citrus industry. II. Univ. of California Press, Berkeley.

Cole, P.J. and M.R. Till. 1977. Evaluation of alternatives to overhead sprinklers for citrus irrigation. Proc. Intl. Soc. Citricult. 1:103-106.

Cooper, W.C. 1961. Toxicity and accumulation of salts in citrus trees on various rootstocks in Texas. Proc. Fla. State Hort. Soc. 74:95-104.

Cooper, W.C. and B.S. Gorton. 1952. Toxicity and accumulation of chloride salts in citrus on various rootstocks. Proc. Amer. Soc. Hort. Sci. 59:143-146.

Cooper, W.C., B.S. Gorton, and E.O. Olson. 1952. Ionic accumulation in citrus as influenced by rootstock and scion and concentration of salts and boron in the substrate. Plant Physiol. 27:191-203.

Cooper, W.C. and A. Peynado. 1959. Chloride and boron tolerance of young lime citrus trees on various rootstocks. Proc. Rio Grande Valley Hort. Soc. 13:89-96.

Croughan, T.P., S.J. Stavarek, and D.W. Rains. 1981. In vitro development of salt resistant plants. Environ. Expt. Bot. 21:317-324.

Dracup, M. 1993. Why does in vitro cell selection not improve the salt tolerance of plant, p. 137-142. In: P.J. Randal, E. Delhaize, R.A. Richards, and R. Munns (eds.). Genetic aspects of plant nutrition. Kluwer, Dordrecht, The Netherlands.

Eaton, F.M. and R.B. Harding. 1959. Foliar uptake of salt constituents of water by citrus plants during intermittent sprinkling and immersion. Plant Physiol. 34:22-26.

Ehlig, C.F. and L. Bernstein. 1959. Foliar absorption of sodium and chloride as a factor in sprinkler irrigation. Proc. Amer. Soc. Hort. Sci. 74:661-670.

El Gazzar, A., A. Wallace, and N. Hemaidan. 1965. Sodium distribution in rough lemon and trifoliate orange seedlings. Soil Sci. 99:387-391.

Embleton, T.W., C.K. Labanauskas, and W.P. Bitters. 1962. The influence of certain rootstocks on the concentration of boron, iron, manganese, and other elements in lemon leaves, and on boron toxicity symptoms. Proc. Amer. Soc. Hort. Sci. 80:285-290.

Flowers, T.J. and A.R. Yeo. 1995. Breeding for salinity resistance in crop plants: Where next? Austral. J. Plant. Physiol. 22:875-884.

Furr,J.R. and C.L. Ream. 1968. Shoot growth of 'Valencia' orange in relation to salinity and salt accumulation. Proc. Amer. Soc. Hort. Sci. 93:153-158.

Garcia-Agustin, P. and E. Primo-Millo. 1995. Selection of a NaCl-tolerant citrus plant. Plant Cell Rpt. 14:314-318. 
Goell, A. 1969. Salinity effects on citrus trees. Proc. First Intl. Citrus Symp. 3:1819-1824.

Goldberg, D. and M. Shmueli. 1971. Sprinkle and trickle irrigation of green pepper in an arid zone. HortScience 6:559-562.

Greenway, H. and R. Munns. 1980. Mechanisms of salt tolerance in nonhalophytes. Ann. Rev. Plant Physiol. 31:149-190.

Grieve, A.M. 1983. Salt uptake by citrus trees. Austral. Citrus News 59:3,8.

Grieve, A.M. and R.R. Walker. 1983. Uptake and distribution of chloride, sodium and potassium ions in salt treated citrus plants. Austral. J. Agr. Res. 34:133-143.

Harding, R.B., M.P. Miller, and M. Fireman. 1958a. Absorption of salts by citrus leaves during sprinkling with water suitable for surface irrigation. Proc. Amer. Soc. Hort. Sci. 71:248-256.

Harding, R.B., P.F. Pratt, and W.W. Jones. 1958b. Changes in salinity, nitrogen, and soil reaction in a differentially fertilized irrigated soil. Soil Sci. 85:177-184.

Hem, J.D. 1970. Study and interpretation of the chemical characteristics of natural water. U.S. Dept. Interior, Geological Survey Water-Supply Paper 1473. U.S. Govt. Printing Office, Washington, D.C.

Hewitt, A.A. and J.R. Furr. 1965. Influence of salt source on the uptake of chlorides by selected citrus seedlings. Proc. Amer. Hort. Sci. 86:201-204.

Jones, W.W., H.E. Pearson, E.R. Parker, and M.R. Huberty. 1952. Effect of sodium in fertilizer and in irrigation water on concentration in leaf and root tissues of citrus trees. Proc. Amer. Soc. Hort. Sci. 60:65-70.

Kirkpatrick, J.D. and W.P. Bitters. 1969. Physiological and morphological response of various citrus rootstocks to salinity. Proc. First Intl. Citrus Symp. 1:391-399.

Kochba, J., G. Ben-Hayyim, P. Spiegel-Roy, S. Saad, and H. Neumann. 1982. Selection of stable salt-tolerant cell lines and embryos in Citrus sinensis and C. aurantium. Z. Pflanzenphysiol. 106:111-118.

Koo, R.C.J., C.A. Anderson, I. Stewart, D.P.H. Tucker, D.V. Calvert, and H.K. Wutscher. 1984. Recommended fertilizers and nutritional sprays for citrus. Inst. Food Agr. Sci. Univ. Fla. Bul. 536D.

Levy, Y. and B.J. Boman. 2004. Water management in citrus, p. 268-304. In: S. Singh, V.J. Shivanker, A.K. Srivastava, and I.P. Singh (eds.). Advances in citriculture. Jagmander Book Agency, New Delhi, India.

Levy, Y., D. Columbus, D. Sadan, and J. Lifshitz. 1999a. Trickle linear gradient for assessment of the salt tolerance of citrus rootstocks in the orchard. Irr. Sci. 18:181-184.
Levy, Y., J. Lifshitz, Y. De Malach, and Y. David. 1999b. The response of several Citrus genotypes to high-salinity irrigation water. HortScience 34:878-881.

Levy, Y. and J. Shalhevet. 1985. Irrigation of a mature orchard with high salinity water-Comparisons of two cultivars and three rootstocks. Gilat Expt. Sta. Rpt., Agr. Res. Org., Bet Dagan, Israel.

Levy, Y. and J. Shalhevet. 1990. Ranking the salt tolerance of citrus rootstocks by juice analysis. Sci. Hort. 45:89-98.

Levy, Y. and J. P. Syvertsen. 2004. Irrigation water quality and salinity effects in citrus trees. Hort. Rev. 30:37-82.

Libal-Weksler, Y., M. Nir, G. Ben-Hayyim, and E. Tel-Or. 1994. Starch metabolism in salt tolerant and salt sensitive Shamouti callus. Plant Physiol. 32:655-659.

Lyons, C.G., Jr. 1977. Water management in Texas citrus. Proc. Intl. Soc. Citricult. $1: 117$.

Maas, E.V. 1985. Crop tolerance to saline sprinkling water. Plant Soil 89:273-284.

Maas, E.V. 1993. Salinity and citriculture. Tree Physiol. 12:195-216.

Newcomb, D.A. 1978. Selection of rootstocks for salinity and disease resistance. Proc. Intl. Soc. Citricult. 1:117-120.

Pearson, G.A., J.A. Goss, and H.E. Hayward. 1957. The influence of salinity and water table on the growth and mineral composition of young grapefruit trees. Proc. Amer. Soc. Hort. Sci. 69:197-203.

Pearson, H.E. and M.R. Huberty. 1959. Response of citrus to irrigation with water of different chemical characteristics. Proc. Amer. Soc. Hort. Sci. 73:248-256.

Piqueras, A., J.A. Hernandez, E. Olmos, E. Hellin, and F. Sevilla. 1996. Changes in antioxidant enzymes and organic solutes associated with adaptation of citrus cells to salt stress. Plant Cell Tissue Organ Cult. $45: 53-60$.

Pratt, P. F. and D. L. Suarez. 1990. Irrigation water quality assessment, p. 220-236. In: K.K. Tanji (ed.). Agricultural salinity assessment and management. Manuals and reports on engineering practice: No. 71. Amer. Soc. Civil Eng., New York.

Ream, C.L. and J.R. Furr. 1976. Salt tolerance of some Citrus species, relatives, and hybrids tested as rootstocks. J. Amer. Soc. Hort. Sci. 101:265-267.

Shalhevet, J.D. 1984. Management of irrigation with brackish water, p. 398-318. In: I. Shainberg, J.D. Shalhevet, and H. Kamburov (eds.). Soil and salinity under irrigation, processes and management. Springer-Verlag, New York.
Shalhevet, J., D. Yaron, and U. Horowitz. 1974. Salinity and citrus yield-An analysis of results from a salinity survey. J. Hort. Sci. 49:15-27.

Shmueli, M. and D. Goldberg. 1971. Sprinkle, furrow and trickle irrigation of muskmelon in an arid zone. HortScience 6:557-559.

Spiegel-Roy, P. and G. Ben-Hayyim. 1985. Selection and breeding for salinity tolerance in vitro. Plant Soil 89:243-252.

Storey, R. and R.R. Walker. 1999. Citrus and salinity. Sci. Hort. 78:39-81.

Syvertsen, J.P., B. Boman, and D.P.H. Tucker. 1989. Salinity in Florida citrus production. Proc. Fla. State Hort. Soc. 102:61-64.

Syvertsen, J.P., J. Lloyd, and P.E. Kriedemann. 1988. Salinity and drought stress effects on foliar ion concentrations, water relations and photosynthetic characteristics of orchard citrus. Austral. J. Agr. Res. 39:619-627.

Tanji, Kenneth K. 1990. Nature and extent of agricultural salinity, p. 1-17. In: K.K Tanji (ed.). Agricultural salinity assessment and management. Manuals and reports on engineering practice: No. 71. Amer. Soc. Civil Eng., New York.

Walker, R.R., E. Torokfalvy, A.M. Grieve and L.D. Prior. 1983. Water relations and ion concentrations of leaves on salt stressed citrus plants. Austral. J. Plant Physiol. 10:265-277.

Wutscher, H.K. 1979. Citrus rootstocks. Hort. Rev. 1:237-269.

Wutscher, H.K., A. Peynado, W.C. Cooper, and H. Hill. 1973. Method of irrigation and salt tolerance of citrus rootstocks. Proc. Intl. Soc. Citricult. 1:299-306

Zekri, M. 1993. Salinity and calcium effects on emergence, growth and mineral composition of seedlings of eight citrus rootstocks. J. Hort. Sci. 68:53-62.

Zekri, M. and L.R. Parsons. 1989. Growth and root hydraulic conductivity of several citrus rootstocks under salt and polyethylene glycol stresses. Physiol. Plant. 77:99-106.

Zekri, M. and L.R. Parsons. 1990. Calcium influences growth and leaf mineral concentration of citrus under saline conditions. HortScience 25:784-786.

Zekri, M. and L.R. Parsons. 1992. Salinity tolerance of citrus rootstocks: Effects of salt on root and leaf mineral concentrations. Plant Soil 147:171-181. 